(and understandably so) that this is unattainable. But this is an indispensable dialogue between scholars which must, and undoubtedly will, continue for a very long time.

A new and interesting feature in the discussions was the attempt to agree on identical French and English words, and to provide agreed "cultural-stratigraphic" definitions to fit archaeological requirements. It remains to be seen whether the languages themselves will tolerate these libertics. The advantages may bo illusory when it is realized that African archaeologists must in any case accept that African scientific literature is bound to be shared between English and French.

The need for more intensive ethnographic research by scholars who really understand material culture and technology, as well as their value and their limitations in archaeological studies, was referred to many times. It is surprising how few people will admit that the two disciplines, ethnology and archaeology, are essentially different approaches to the same subject.

The recommendations contain a great many excellont ideas, including pleas for standardization of methods of presentation and illustration, which may in fact be of even greater practical value than the revision of terminology. It would porhaps have been instructive, and a good augury for the ideal of closer collaboration, to have redrawn (with authors' permission) all the maps, plans and archaeological drawings (using metric scales throughout !) in this impressive volume-good as many of the drawings are - to the excellent standard already set in Inventaria Archaeologica Africana, which aro, in my opinion, much superior to Fiches Typologiques Africaines.

No library of African prehistory can afford to be without this volume, the production of which was only made possible by a Wenner-Gren subvention of $\$ 10,000$ to the University of Chicago Press. In common with other books from abroad its price, which certainly seems high, has, of course, been augmented by sterling devaluation. Bernard FagG

\section{ICE OR FLOOD?}

Studies on Glaciers preceded by the Discourse of Neuchătel

By Louis Agassiz. Translated and edited by Albert V. Carozzi. Pp. lxxi $+213+32$ plates. (New York and London: Hafner Publishing Co., 1967.) \$27.50.

To replace the waters of the biblical flood as the main agent for dumping rock debris by transport of rocks by ice was perhaps less of an upset to man's beliefs than the theory of evolution which came twenty years after Agassiz propounded his ideas on ice ages. Both ideas inevitably aroused much controversy.

Agassiz was not the first to realize that processes seen to be taking place on alpine glaciers could also be used to invoke the idea that vast ice sheets once covered northern Europe. However, much of the credit for convincing the scientific world at large of the occurrence of past ice ages is his. He had the stature and ability to do this-starting with considerable effect in 1837, when, as the young president of the Société Helvétique des Sciences Naturelles, he presented his ideas on ice ages in his "Discours de Neuchâtel". The address apparently had much impret, and even though the basic idea of ice ages was eventually adopted by the scientific world, his physiological view of natural processes could hardly have appealed to many in the audience who were present. Some account of the discussion which followed the discourse would have been illuminating.

Professor Albert V. Carozzi of the University of Tllinois has now made available in English the "Discourse" because "this fundamental and controversial paper, often quoted, is nevertheless very little known, because it was never printed separately and the Actes de la Société Helvétique were published in an extremely small number of copies". The major part of this publication is, however, the first translation into English of Agassiz's "Etudes sur les Glaciers". Whereas the "Discourse" is full of onthusiasm and impact, the "Studies on Glaciers" gives an account of three years intensive investigation of alpine glaciers, which followed the "Discourso". This period confirmed for Agassiz the main ideas that he had propounded at Neuchâtel.

The handsome volume starts with an introduction setting out the background events and contacts that Agassiz had with Venetz, De Charpentier and others which led up to his "Discourse". Then after the translation of the "Discourse" follows "Etudes sur les Glaciers". This work shows Agassiz at his best, making critical observations on alpine glaciers --their structure, colour, moraines, movement, temperature and action of glaciers on their substratum. This leads up to his chapters on "Oscillations of (Ylaciers during Historical Times", the "Former Extent of Glaciers in the Alps" and then to the major thesis, "Proofs of the Existence of Large Ice Sheets Outside the Realm of the Alps". The broad ficld covered by "Etudes sur les Glaciers" shows Agassiz laying many of the foundations of modern glaciology and is well worth reading. There are some weaknesses in his physical arguments, but for an energetic and intelligent study the work is adinirable.

An accompanying folio or atlas was published at the same time as the studies. The series of eighteen lithographs drawn by his artist Bettanier in the days preceding glacier photography are handsomely reproduced with overlays, at only a small reduction in size on the original. An active glaciologist will perhaps feel that the maps and diagrams in the original atlas might also have been reproduced. However, the excellent lithographs and the general standard of production of the text, give the impression that one is dealing with a work of art rather than an early scientific treatise, which, except for the folio atlas, was published as a modest octavo volume. The price, although high, is reasonable for the quality of production, and makes the book a worthy collector's piece for those interested in the early development of our ideas on glaciers.

G. de Q. RobiN

\section{ULTRAMAFIC ROCKS}

\section{Ultramafic and Related Rocks}

Edited by P. J. Wyllie. Pp. xvii + 464. (New York and London: John Wiley, 1967.) 211 s.

Compilation on a broad but specific aspect of the earth sciences has now become a standard method of presenting an up to date review of the data and outstanding problems of these specialized subjects on a scale not possible in a general textbook. The present volume is thus essentially aimed at research workers, teachers and advanced students who wish to obtain an authoritative review of the current position without the necessity of reading a large volume of original papers. In the field under review the reader is presented with a comprehensive account of the wide variety of ultramafic and related rocks by a total of thirty-three contributors who, with two exceptions, are either North American or British workers.

To some British petrologists the use in the title of ultramafic in preference to ultrabasic may engender some dissent, but the use of the term ultramafic, based as it is on modal composition, is not likely to be widely criticized provided it does not lead to its misuse when discussing magmatic compositions. All the major regimes of the ultramafic rocks, in layered complexes, minor intrusions, zonod complexes, alpine associations including the more recently recognized high-temperature peridotites, kimber- 